\title{
XXXVII. On the presensation which animals have of changes in the weather
}

\author{
Dr. F.A.A. Meyer
}

To cite this article: Dr. F.A.A. Meyer (1801) XXXVII. On the presensation which animals have of changes in the weather, Philosophical Magazine Series 1, 11:43, 211-216, DOI: $10.1080 / 14786440108675985$

To link to this article: http://dx.doi.org/10.1080/14786440108675985

曲 Published online: 18 May 2009.

Submit your article to this journal $\sqsubset \pi$

Џ Article views: 2

Q View related articles $\sqsubset$ 
This fimilarity in the means by which both electricity and galvanifm appear to be excited, in addition to the refemblance that has been traced between their effects, fhows that they are both effentially the fame, and confirms an opinion that has already be: $n$ advanced by others, that all the differences difcoverable in the effects of the latter, may be owing. to its being lefs intenfe, but produced in much larger quantity.

XXXVII. On the Prefenfation wubicb Animals base of Changes in the Weatber. By Dr. F. A. A. MEYER, at Gittingen*.

\section{$\mathbf{I}$}

SHOULD only repeat what has been already long known, if I hould attempt to prove that, by the great enlargement of our knowledge refpecting the natural hiftory of foreign animals, by means of various learned travellers, we are now enabled to explain, to the fatisfaction of the judicious naturalift, many phænomena which occur among indigenous animals. The fenfations which take place in animal bodies before a change of weather, which animals exprefs by various external appearances, and which, without taking part in the difpute whether animals are endowed or not with fouls, may be called a prefenfation, feem however to require confiderable explanation. I am well aware that it will be impoffible for me to explain things which have not as yet been perfectly explained by men of the greateft knowledge; but I am convinced that every thing which can contribute to the illuftration of an obf cure fibject deferves to be fubmitted to a proof, and that it is of ufe to communicate even fongle obfervations on points concerning which fyftems cannot be formed till after the expiration of centuries. Confidering the fubject in this point of view, I prefent the following.

Prelenfation may be admitted under three heads:- $\mathrm{I}$. The prefenfation which animals have of dry fair weather. II. The prefenfation which animals have of rainy weather. III. The prefenfation which animals have of ftormy weather.

What regards the two firft claffes of the prefenfation of animals is taken from the Göttingen Pocket Almanac for the year 1779 , the editor of which, as is well known, was at that period counfellor Lichtenberg. In that work I found the moft authentic obfervations of the lateft writers collected

"From Magazin für das $\mathrm{N}_{e}$ uefta aus de: Pbyfik, vol. vii. 
together. The obfervations refpecting the third clars I collected myfelf.

Firft, then, refpecting the prefenfation which animals have of fair dry weather.

Clear, dry weather generally follows after wet weather, when the atmofphere has been freed from the vapours collected in it by their falling to the earth in rain. Clonds as well as rain are the means by which the air trees itfelf from the electric vapours that are continually arifing; and if thefe again fall down, it appears very natural that animals, which live chiefly in the open air, thould exprefs, by various external movements, the edfe with which they breathe, and perform all the vital functions. From this principle it feems not difficult to explain the following obfervations:

The fluttering of bats in the evening, beetles flying about on the highways, and the fporting of gnats towards funfet, require no explanation. I thall only remark, what is already well known to every obferver, that this prefenfation is highly ufeful to bats as well as to infeets. Every hlower of rain would render it impoffible for them to fly, as their wings are not fecured by any oily matter againit moifture: they would therefore be rendered much heavier by rain, and unfit for flying, and they could not be fo eafily placed again in folds, which, confidering the ftructure of thefe animals, is abfolutely neceflary, as when they have remained dry.

The fame principle feems to be applicable to the high flight of larks and fwallows, which perhaps haften to the upper regions of the atmofphere becaufe they are freer from vapours and more fuited to them, and becaufe the lower regions, being more loaded with vapours, afford them lefs plea. fure than thofe above. The infects alfo which they puriue for food take then, perhaps, a higher fiight.

The croaking of the green water-frog in ponds I cannot fufficiently explain; but it feems to exprefs the pleafure ariting from the greater quantity of infects then flying about, and which they can catch with more eafe and convenience. But clear dry weather is not fo agreeable to frogs as the return of warm weather. If they make a noife in the time of cold rain, warm dry weather will follow. But if the dry weather proceeds from raw winds, and if warmth and rain fucceed, their noife may foretel rain; and therefore Lin. næus's rule predicit pluvian will lofe nothing of its truth. He fcems fo much the more to be right, as nore raw than warm dry davs take place in the climate of Sweden. I have, to my great inconvenience, experienced the truth of his affer- 
vien, on journeys which I was under the neceffity of continuing for feveral days.

That the weather-fin * (cobitis folfilis) leaves the watcr quite pure during dry weather, and the green frog + fits at the top of the glais, may proceed from the lighter or heavier ftate of the atmofphere, particularly as the latter is remarkably font of cleanimefs and moderately pure air.

The affembling of ravens in the fieids, and the finging of the wood-pigeon, may be eafily accounted for from the above principles.

I have never fecn birds in good weather drefs their feathers with oil from their fat glands, in order to fecure them from rain; but I have obferved many do fo when the atmofphere was overcaft, and when there was an appearance of rain. I fhould therefore include this circumftance in the following clats, did not experience admit alfo of another explanation, viz. that the birds, from the atmofphere becoming ligbter, hope for the fpeedy arrival of dry weather, and therefore anoint themfelves, and fecure their feathers from moifture, that they may be able to fly higher than uftal with the lefs impediment. If the laft explanation ought not to be altogether rejected, as I do not think it can, we may admit of this obfervation; efpecially as all the experience of men worthy of belief allows of no reafoning to be brought againft it.

The expreffion of animals which thow a prefenfation of rainy weather may be explained partly from the increafing weight of the atmofphere, partly from their manner of living, and partly from the want of moilture which is necellary to their exiltence.

The reftlefinefs of domeftic cattle may proceed from many caufes. It is known that the atmofphere in fummer, before rain falls, is generally heavier, on account of the electric vapour that arifes. The infects which infeft cattle, and which mark this heavinefs, become then more numerous, and, getting into the ftalls where the cattle are kept, torment them and make them reftlefs. The afcending vapour has alfo perhaps fome influence on the fkins of thefe animals, which ceafes when the earth does not fuffer fo much vapour to efcape as before; or the air, too Atrongly charged with electricity, excites in them an unpleafant fenfation. It in-

* So called becaufe kept in Germany to forctel changes of the weather. When the wtather is fine they continue quiet, but befure a frorm or rain are very retlefs. - EDIT.

$t$ This animal, though very common in many parts of Europe, is not found in England.-Fin. 
deed appears frange to explain the fame phenomenon from two perfectly oppoite caufes, a want and an excefs of electricity; but we know cafes of the like kind in medicine, fuch, for example, as that where the cramp and heep produces atonia. Penple who have wounds or old ulcers feel, on a change of weather, a contraction and burning in thofe parts; and why thould not fuch affections take place in animals?

All thefe grounds taken together will be fufficient, in ny opinion, to explain why horfes and affes rub themfelves, fhake their heads, and fnuff the air by turning up their nofes; why affes bray much, and jump about; why cattle fcrape up the earth, and ftamp with their feet; and why fwine, though not hungry, eat greedily and dig up the earth a great deal with their fnouts. The reftleffnes, running about, fcraping with the feet, and eating grafs, among dogs; and moles continually throwing up the earth, can all be deduced from the fame; as well as the cats dreffing themfelves.

I have remarked that cocks crow on every change of weather, befides at the ufual time. They as well as pigeons haften to their places of hicher in order to be fecured againft the rain, the approach of which they muft be fenfible of, by the continually increafing weight of the atmofphere.

The caufe of fowls, pigeons, quails, and other birds, wafhing themfelves, appears to me to be a certain heat or itching, which they win by thefe means to renove.

Swallows, in all probability, take a low flight on the approach of rainy weaiher, becaufe the electric atmofphere is too heavy for them, and becaufe they bave not fufreient ftrength to mount above it. But cranes, as being ftronger hirds, employ all their firength to rife above it, and therefore fly fo high:

I have remarked in ravens, that weir croaking, unlefs when they fmell carrion, proceeds from fear. They obferve perhaps, by the atmofphere ftill becoming heavicr, that a ftorm highly difagretable to them will foon take place, and therefore they croak, and attach themfelves to trees; and when they are ftartied by any thing uncommon, they take a high flight, making a loud cry. They eafly difcover their perfecutors among men, and always cry with a loud noife as long as they think they are purfucd by them.

That jackdaws, on the approach of rainy weather, flap their wings, and pick their feathers with their bills, may be explaincd partly by an unpleafant fenfation before rain, and partly from the ftate of the atmolphere.

To the before-mentioned itching or burning fenfation I refer alfo the bathing and plunging of water-iowl. That the 
birds of the foreft Mould haten to their mefts is very natural, as from the ftate of the atmofphere they muft apprehend rain.

The crying of peacocks, except at pairing time, appears to be a plisuomenon analogous to the crowing of cocks. I have often remarked it on a change of weather, and often even on a change of wind.

That ftorks and cranes place their bills under their wings, is a phxnomenon remarked alfo among domeftic fowls when thev fly to their roots to fecure themfelves againft rain. Their pecking their breats feems to figuify an itching fenfation in that part of their bodics.

The croaking of the male green or tree frog feems to clenote an unpleafant fenfation, for in fine weather I never heard them fend forth the fmalleft cry. But the appearance of toads implies a pleafant lenfation, as thefe animals are fo fond of living in dirt.

Ants labour with great diligence, and bees haften home, and do not fly far from their hives, becaufe they follow their inftinet. The former endeavour to complete their habitations and to fecure themfelves better againft rain, and perhaps to lay up provifion for the rainy feafon. The latter baften home to their hives, and fly no more abroad, becaufe the wet would impede them in their flight and labour.

Gnats $\left(c s^{\prime} p s\right)$ come into houfes to fecure themfelves from rain, which would impede their flight, and there they attac themflies to the legs to procure that nourithment which is denied them without.

The increafed biting of fleas I cannot explain, as the natural hiftory of thefe infests is as yet too oblcure.

Earth-worms creep from their holes through inflinet, as they can move thenfelves forwad only upon earth that is llippery.

A prefenfation of ftoms I have obferved only among the perfect of the mammalia, and as yet but among two, riz. man and the dog. Buth thefe feem to have a fenfe of the increafed elestricity of the atmofphere. It appears in general, that the more imperfect animals remark only the approach of dry weather ; the more perfect, the approach of ran; and the molt perfect, the approach of ftorms. All auimals, perhaps, with their external fenfes, and all plants by their organs, are lenfible of the variations of the weather : but plants are not here my object, and it is not neceflary to prove the inflnence of the weather on them, as it is fufficiently apparent to every obferver. Here I allude only to the external expreffion of internal fenfations, as may be feen by the ad$\mathrm{O}_{4}$ duced 


\section{Prefenfation of Aninals of Cbanges in the Weatior.}

duced inftances; elfe one might confider the fhutting and expanding of many plants as foreboding variations of the weather.

The $\mathrm{dog}$, on the approach of rainy weather, expreffes figns of uneafinefs; fcratches himfelf, becaufe the fleas then bite him with more violence; digs up the earth with his feet, runs round, and cats grafs : he is accuitomed, however, to do the latter when he is very hot, perhaps to cool himfelf, and in general a ftorm follows foon after. Before a ftorm he evaporates more ftrongly, fo that his fimell becomes intolerable; he creeps in a dejected manner to his mafter, and lies quiet. The cat alfo feens to have this in common with the dog, that the creeps to her mafter alfo on the approach of a ftorn. But all thefe phanomena require a further explanation.

The moft perfect of all animals, man, is on the approach of ftorms only fibject to certain unpleafant finfations; but thefe muft teach him, in the moft ftriking manner, that his fpiritual part, even though it difengages it cif fo much from oppreffive cares, is irremediably connected here below with a fluggith budy, which frequently excrciles tyrannic fway over the foul. Men in a firmd fiate of health are fubjected, on. the approach of ftormy weather, to a heavinefs of body and mind, a want of capacity to perform their viual occufations, a yawning and relaxation, which are linhiy duagreeable. Thefe are often accompanied alfo with a fenfation of heat. All thefe phanomena appear in fome more and in others lefs, and in fome do not take place at all : but the laft cafe happens very rarely. Sick perfons, or thofe whote juices are corrupted, experience, befides the above, an itching heat in thofe parts of their bodies which are covered; and ronan who hove old wounds, nleers, and the like, have in thete uncomnon fenfations. Many of thefe may be aferibed to peripiration checked by the great heat; though, as Weikard, a philofophic phyfician, afterts, the want of electric matter in the body may have fome thare in them alfo.

When ftormy weather happens in winter, thefe fenfations, a: well as the before-mentioned prefenfation of animals, do not take place; at leaft no one has ever oblerved them. This, in all probability, arifes from the intuence of the realon.

I muft conclude this effay with requefting, that what I have here faid may be confidered, as it really is, an hypo. thetic explanation of well known facts. 